\title{
FREQUENCY OF OCCURRENCE OF ACANTHOCEPHALANS (ACANTHOCEPHALA) AND CESTODES (CESTODA) IN ALIMENTARY TRACTS OF THE SEA TROUT SMOLTS (SALMO TRUTTA M. TRUTTA) GROWN IN THE DRAINAGE AREA OF THE RIVER REGA AND THEIR IMPACT ON FISH CONDITION CZĘSTOTLIWOŚĆ WYSTĘPOWANIA KOLCOGLOWÓW (ACANTHOCEPHALA) I TASIEMCÓW (CESTODA) W PRZEWODACH POKARMOWYCH SMOLTÓW TROCI WĘDROWNEJ (SALMO TRUTTA M. TRUTTA) WYROSEYCH W ZLEWNI RZEKI REGI ORAZ ICH WPLYW NA KONDYCJĘ RYB
}

Department of Salmonid Fishes Management, Agricultural University of Szczecin, Poland

The present paper demonstrates results of analysis of 247 alimentary tracts of sea trout smolts (Salmo trutta m. trutta) grown in the drainage area of the river Rega (Pomerania). Frequency of occurrence of acanthocephalans and cestodes in the alimentary tract was determined, as well as their impact on fish condition.

\section{INTRODUCTION}

Analysis of the alimentary tracts of sea trout smolts (Salmo trutta m. trutta L.) grown in the drainage area of the river Rega, showed the presence of acanthocephalans (Acanthocephala) and cestodes (Cestoda). The inflammation of intestine observed in the smolts, caused by the acanthocephalans, might have certain impact on the host, especially when the rate of infection was high. Could therefore abundant occurrence of the acanthocephalans destabilise the host-parasite balance and cause the worsening of condition (Kocylowski and Miączyński 1960) and even the death of fish? (Listow 1895; Meyer 1932; Meyer 1933 after Bychowsli 1962; Steinstrasser 1936 after Grabda 1971; Prost 1994). The frequency of occurrence of the acanthocephalans and cestodes in the alimentary tracts, as well as their influence on the condition of sea trout smolts from the river Rega was the main research objective of the present paper. 


\section{MATERIAL AND METHODS}

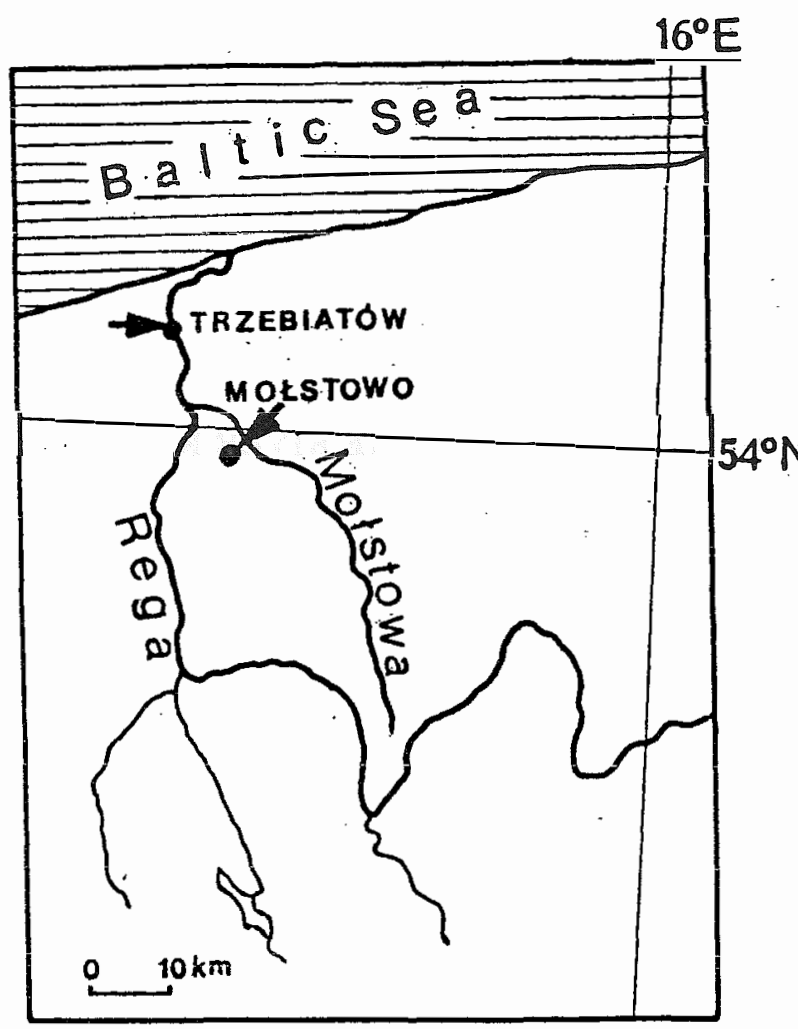

Fig. 1. Diagramatic map of the drainage area of the river Rega. The collection sites of the sea trout smolts examined marked with arrows

Sea trout smolts examined for intestinal parasites were from the drainage area of the river Rega emptying to the south-western Baltic Sea. They were captured in the lower river Rega and its right tributary Mołstowa during their migration to the sea in spring (Fig. 1). The sea trout smolts were collected using the winged trap, above the weir of power plant in the village of Mołstowo (Chełkowski et al. 1982). The weir made the upstream spawning migration of the sea trout impossible (Chelkowski 1974). Therefore the smolts caught, grew from feeding alevins released in previous years (Chełkowski et al. 1982). Fish catches in Rega were performed in the trap in the inflow canal of the power plant in Trzebiatów (Chelkowski 1978). These smolts grew in the drainage area of the river Rega and could come either from natural spawning or alevin stocking (Chelkowski 1974). Fork length of the sea trout smolts with alimentary tracts taken to examine for parasites, was recorded to the nearest $\mathrm{mm}$, and weight of the gutted fish (i.e. without alimentary tract, liver, heart, and gonads) - to the nearest gram. In the present paper smolts were grouped in 1-cm length classes. For example the 11-cm length class comprised the individuals measuring $101-110 \mathrm{~mm}$, while $12-\mathrm{cm}$ class $111-120 \mathrm{~mm}$.

In order to estimate condition of smolts examined the coefficient of condition $(K)$ was calculated using the formula:

$$
K=\frac{G \times 100}{L^{3}}
$$


where: $G$ according to Clark (after Suworow 1954) corresponds with Fulton's formula for the gutted fish weight in grams (as opposite for the total fish weight which was considered by Fulton), and $L-$ fork length in $\mathrm{cm}$.

Table 1

Collection sites, season and yields of the sea trout smolts from the drainage area of the river Rega

\begin{tabular}{|l|l|l|c|}
\hline River & $\begin{array}{c}\text { Collection } \\
\text { site }\end{array}$ & \multicolumn{1}{|c|}{$\begin{array}{c}\text { Collection } \\
\text { season }\end{array}$} & $\begin{array}{c}\text { Number of } \\
\text { individuals } \\
\text { examined }\end{array}$ \\
\hline Rega & Trzebiatów & spring 1965 & 12 \\
Rega & Trzebiatów & spring 1966 & 8 \\
Rega & Trzebiatów & spring 1967 & 5 \\
Mołstowa & Mołstowo & spring 1979 & 222 \\
\hline \multicolumn{3}{|c|}{ Total } & 247 \\
\hline
\end{tabular}

The number of sea trout smolts from the Rega, examined for intestine parasites with regard to the site and season of catch, is presented in Tab. 1. A total of 247 alimentary tracts were analyzed from one-, two- and threeyear-old smolts (Chelkowski 1978; Chełkowski et al. 1982).

\section{RESULTS}

Acanthocephalans attach to the intestinal wall with hooks situated on a proboscis. In the place of attachment there is a hyperaemia indicating inflammation of mucosa and damage of intestinal wall. High infection intensity of acanthocephalans caused inflammation of the alimentary tract. Focal convex (nodular) rubefactions cá $2 \mathrm{~mm}$ in diameter located on external side of intestine indicate the presence of acanthocephalans in alimentary tract of fish examined. Acanthocephalans are flesh-coloured to light-brown, sometimes with an orange shade. The biggest specimen with proboscis was $18 \mathrm{~mm}$ long. The acanthocephalans examined were 8-16 mm long.

Cestode strobiles occurred only in pyloric caeca of the sea trout smolts. They were whitish, measuring about $40 \mathrm{~mm}$.

No impact of the cestodes on pathologic changes of the alimentary tract was recorded. It seems that cestodes do not play such important role as pathogenic factors as acanthocephalans do.

In the material studied, comprising 247 alimentary tracts of the sea trout smolts from the drainage area of the river Rega, 57 (23.1\%) alimentary tracts were free from parasites and $190(76.9 \%)$ were infected with parasites. Acanthocephalans occurred in 164, cestodes in 12, and both cestodes and acanthocephalans in 14 alimentary tracts. As can be seen for the total number of infected fish, acanthocephalans occurred in 178 and cestodes in 26 alimentary tracts (Tab. 2). It was revealed that acanthocephalans occurred in fifteen out of sixteen 1-cm length classes in the range of 11-26 cm (except for the $25-\mathrm{cm}$ length class). Cestodes occurred in six only and lower length classes of smolts, namely in the range from 12 to $20 \mathrm{~cm}$ (except for 13, 18, and 19-cm classes). 
Table 2

Occurrence of acathocephalans and cestodes in the intestines of the sea trout smolts from the drainage area of the river Rega

\begin{tabular}{|c|c|c|r|r|r|c|}
\hline $\begin{array}{c}\text { Length } \\
\text { class } \\
(\mathrm{cm})\end{array}$ & Examined & $\begin{array}{c}\text { Without } \\
\text { parasites }\end{array}$ & $\begin{array}{c}\text { With } \\
\text { parasites }\end{array}$ & $\begin{array}{c}\text { With } \\
\text { acantho- } \\
\text { cephalans }\end{array}$ & $\begin{array}{c}\text { With } \\
\text { cestodes }\end{array}$ & $\begin{array}{c}\text { With both } \\
\text { acanthoce- } \\
\text { phalans and } \\
\text { cestodes }\end{array}$ \\
\hline 11 & 4 & 1 & 3 & 3 & - & - \\
12 & 11 & 4 & 7 & 5 & 1 & 1 \\
13 & 42 & 7 & 35 & 35 & - & - \\
14 & 60 & 13 & 47 & 41 & 2 & 4 \\
15 & 54 & 7 & 47 & 37 & 5 & 5 \\
16 & 29 & 9 & 20 & 16 & 1 & 3 \\
17 & 11 & 2 & 9 & 6 & 2 & 1 \\
18 & 10 & 3 & 7 & 7 & - & - \\
19 & 7 & 3 & 4 & 4 & - & - \\
20 & 5 & 2 & 3 & 2 & 1 & - \\
21 & 1 & 0 & 1 & 1 & - & - \\
22 & 2 & 6 & 2 & 2 & - & - \\
23 & 2 & 0 & 2 & 2 & - & - \\
24 & 2 & 0 & 2 & 2 & - & - \\
25 & - & - & - & - & - & - \\
26 & 1 & 0 & 1 & 1 & - & - \\
\hline Total & 247 & 57 & 190 & 164 & 12 & 14 \\
\hline
\end{tabular}

Table 3

Frequency of occurrence of acanthocephalans and cestodes in the intestines of the sea trout smolts from the drainage area of the river Rega

\begin{tabular}{|c|c|c|c|c|c|c|c|}
\hline \multirow{3}{*}{$\begin{array}{l}\text { Length } \\
\text { class } \\
(\mathrm{cm})\end{array}$} & \multicolumn{4}{|c|}{ Acanthocephalans } & \multicolumn{3}{|c|}{ Cestodes } \\
\hline & \multirow{2}{*}{\begin{tabular}{|c|}
$\begin{array}{c}\text { Number } \\
\text { of fish } \\
\text { with para- } \\
\text { sites }\end{array}$ \\
\end{tabular}} & \multicolumn{2}{|c|}{$\begin{array}{c}\text { Range of } \\
\text { individuals }\end{array}$} & \multirow{2}{*}{ Total } & \multirow{2}{*}{$\begin{array}{c}\text { Number } \\
\text { of fish } \\
\text { with para- } \\
\text { sites }\end{array}$} & \multirow{2}{*}{\begin{tabular}{|c}
$\begin{array}{c}\text { Range of } \\
\text { individuals }\end{array}$ \\
$\begin{array}{c}\text { pyloric } \\
\text { caeca }\end{array}$ \\
\end{tabular}} & \multirow[t]{2}{*}{ Total } \\
\hline & & $\begin{array}{l}\text { pyloric } \\
\text { caeca }\end{array}$ & intestine & & & & \\
\hline 11 & 1 & & 3 & 3 & & & \\
\hline 12 & 2 & & $4-9$ & 13 & 1 & 2 & 2 \\
\hline 13 & 4 & & $3-19$ & 38 & - & - & - \\
\hline 14 & 10 & $1-3$ & $1-18$ & 116 & 4 & $2-16$ & 25 \\
\hline 15 & 16 & $1-5$ & $2-24$ & 158 & 2 & $2-4$ & 6 \\
\hline 16 & 10 & & $1-14$ & 62 & 4 & $2-9$ & 22 \\
\hline 17 & 2 & 1 & 1 & 2 & 3 & $2-11$ & 18 \\
\hline 18 & 4 & & $1-7$ & 13 & 一 & & \\
\hline 19 & 3 & 2 & $4-24$ & 29 & - & & \\
\hline 20 & 2 & & $1-2$ & 3 & 1 & 3 & 3 \\
\hline 21 & 1 & & 18 & 18 & & & \\
\hline 22 & 2 & & $5-15$ & 20 & & & \\
\hline 23 & 2 & & $1-51$ & 52 & & & \\
\hline 24 & 2 & & $7-15$ & 23 & & & \\
\hline 25 & 一 & & - & 一 & & & \\
\hline 26 & 1 & & 1 & 1 & & & \\
\hline Total & 62 & $1-5$ & $1-51$ & 551 & 15 & $2-16$ & 76 \\
\hline
\end{tabular}

Acanthocephalans occurred rarely in the region of the pyloric caeca, more abundantly in the middle and lower intestine. In the region of pyloric caeca occurrence of the acanthocephalans was stated in 10 smolts only. In three cases acanthocephalans occurred only in the region of pyloric caeca, and in seven-in the region of caeca and further part of the intestine. Apart from the occurrence of acanthocephalans only in the region of pyloric caeca, the presence of the worms was recorded in 175 intestines of the sea trout smolts.

The qualitative investigation on the occurrence of intestine parasites in the sea trout smolts was also performed. Analyses involved 62 randomly taken alimentary tracts of the trout smolts from the group of 190 infected fish (Tab. 3). 
This group comprising smolts of all length classes occurred in the sample of 247 fish as well as in the group of fish infected with intestinal parasites.

In the region of intestine with pyloric caeca from 1 to 5 acanthocephalans were recorded, while in the remaining ones from 1 to 51 worms were found.

In the pyloric caeca the occurrence of $2-16$ cestodes was stated. In 62 intestines of the sea trout smolts examined a total of 551 acanthocephalans and 76 cestodes was recorded.

Additional analyses showed that the prevalence of acanthocephalans reached $72.1 \%$. The intensity of acanthocephalan infection covered the range from 1 to 51 specimens. The mean infection reached $8.9 \%$ with the abundance of 6.4 (Tab. 4 ).

Table 4

Infection with intestinal parasites of the sea trout smolts from the drainage area of the river Rega

\begin{tabular}{|c|c|c|c|c|c|c|c|}
\hline \multirow{2}{*}{$\begin{array}{c}\text { Group } \\
\text { of } \\
\text { parasites }\end{array}$} & \multicolumn{2}{|c|}{$\begin{array}{l}\text { Number } \\
\text { of fish }\end{array}$} & \multirow{2}{*}{$\begin{array}{c}\text { Prevalence } \\
(\%)\end{array}$} & \multirow{2}{*}{$\begin{array}{c}\text { Intensity } \\
\text { of } \\
\text { infection }\end{array}$} & \multirow{2}{*}{$\begin{array}{c}\text { Total } \\
\text { number } \\
\text { of parasites }\end{array}$} & \multirow{2}{*}{$\begin{array}{c}\text { Mean } \\
\text { intensity }\end{array}$} & \multirow[t]{2}{*}{ Abundance } \\
\hline & Examined & Infected & & & & & \\
\hline Acanthocephalans & 247 & 178 & 72.1 & $1-51$ & 551 a) & $8.9 \mathrm{~b})$ & $6.40^{\mathrm{c})}$ \\
\hline Cestodes & 247 & 26 & 10.5 & $2-16$ & $76^{a)}$ & $5.1^{d)-}$ & $-0.53 \mathrm{e})$ \\
\hline
\end{tabular}

a) Qualitative calculations of occurrence of intestine parasites were performed on 62 randomly chosen alimentary tracts with acanthocephalans where in 15 cases cestodes occurred as well.

b) The mean intensity is a quotient of the number of acanthocephalans found and the number of fish infected.

c) The abundance is a quotient of the number of acanthocephalans found and the number of fish examined. The question is how many fishes were investigated for 62 smolts with acanthocephalans. However, if the ratio of total number of fish examined for endoparasites to fish with acanthocephalans is known, it is not difficult to calculate this value: $247 \div 178=x \div 62$, so $x=86$. Therefore $551 \div 86=6.4$.

d) $76 \div 15=5.1$ (see a) and b)).

e) $247 \div 26=x \div 15 ; x=142.5 ; 76 \div 142.5=0.53($ see $c)$ ).

Prevalence of the cestode infection reached $10.5 \%$, with the intensity of infection 2-16 individuals in the intestine. The mean intensity amounted 5.1 individuals with the abündance of 0.53 .

In addition, the prevalence tendency of acanthocephalans in individual length classes of smolts was analyzed (Tab. 5). It appeared that in the respective sixteen length classes of fish examined, prevalence of acanthocephalans was within $25-100 \%$. It seems to be interesting that in the higher length classes the prevalence of acanthocephalan infection appeared to be higher when compared to the lower length classes.

Among the intestinal parasites of the sea trout smolts from the drainage area of the river Rega, the following species have been recorded: Acanthocephala-Metechinorhyn- 
Table 5 chus truttae (Schrank, 1788) (cf. Bychow-

Prevalence of acanthocephalans infection in length classes of the sea trout smolts from the drainage area of the river Rega

\begin{tabular}{|c|c|c|c|}
\hline \multirow{2}{*}{$\begin{array}{c}\text { Length } \\
\text { class (cm) }\end{array}$} & \multicolumn{2}{|c|}{ Number of fish } & Prevalence \\
\cline { 2 - 3 } & Examined & Infested & \\
\hline 1 & 4 & 3 & 75 \\
12 & 11 & 6 & 55 \\
13 & 42 & 35 & 83 \\
14 & 60 & 45 & 75 \\
15 & 54 & 42 & 78 \\
16 & 29 & 19 & 66 \\
17 & 11 & 7 & 63 \\
18 & 10 & 7 & 70 \\
19 & 7 & 4 & 57 \\
20 & 5 & 2 & 40 \\
21 & 1 & 1 & 100 \\
22 & 2 & 2 & 25 \\
23 & 2 & 2 & 100 \\
24 & 2 & 2 & 100 \\
25 & - & - & - \\
26 & 1 & 1 & 100 \\
\hline Total & 247 & 178 & 72 \\
\hline
\end{tabular}
ski 1962) and Cestoda-Cyathocephalus truncatus (Pallas, 1781) (cf. Bychowski 1962; Prost 1994).

Lengths and weights of 247 fish examined showed the condition of the trout smolts from the Rega. It was revealed, that values of the condition coefficients of the smolts investigated in particular length classes ranged from 0.70 to 0.83 , with the mean value of 0.79 for the whole period of study. In the group of fish free from parasite ( $\mathrm{n}=57$ specimens) values of the condition coefficients of the smolts investigated in particular length classes covered the range $0.70-0.84$, with the mean value of 0.78 for the whole period of study.

Table 6

Coefficient of condition of the sea trout smolts from the drainage area of the river Rega

\begin{tabular}{|c|r|c|c|c|c|c|}
\hline \multirow{2}{*}{$\begin{array}{c}\text { Length } \\
\text { class } \\
\text { (cm) }\end{array}$} & \multicolumn{9}{|c|}{ For fish } \\
\cline { 2 - 7 } & \multicolumn{2}{|c|}{ All } & \multicolumn{2}{c|}{$\begin{array}{c}\text { Free } \\
\text { from parasites }\end{array}$} & \multicolumn{2}{c|}{$\begin{array}{c}\text { Infected with } \\
\text { intestinal parasites }\end{array}$} \\
\cline { 2 - 7 } & n & value & n & value & n & value \\
\hline 11 & 4 & 0.78 & 1 & 0.84 & 3 & 0.76 \\
12 & 11 & 0.81 & 4 & 0.74 & 7 & 0.85 \\
13 & 42 & 0.76 & 7 & 0.71 & 35 & 0.77 \\
14 & 60 & 0.80 & 13 & 0.79 & 47 & 0.81 \\
15 & 54 & 0.80 & 7 & 0.81 & 47 & 0.80 \\
16 & 29 & 0.79 & 9 & 0.83 & 20 & 0.77 \\
17 & 11 & 0.83 & 2 & 0.83 & 9 & 0.83 \\
18 & 10 & 0.82 & 3 & 0.78 & 7 & 0.85 \\
19 & 7 & 0.75 & 3 & 0.70 & 4 & 0.77 \\
20 & 5 & 0.70 & 2 & 0.70 & 3 & 0.70 \\
21 & 1 & 0.80 & 0 & - & 1 & 0.80 \\
22 & 2 & 0.80 & 6 & 0.81 & 2 & 0.77 \\
23 & 2 & 0.70 & 0 & - & 2 & 0.70 \\
24 & 2 & 0.77 & 0 & 0.83 & 2 & 0.77 \\
25 & - & - & - & - & - & - \\
26 & 1 & 0.80 & - & - & 1 & 0.80 \\
\hline Total & 257 & & 57 & & 190 & \\
\hline $\bar{x}$ & & 0.79 & & 0.78 & & 0.80 \\
\hline
\end{tabular}


In the group of fish infected with intestinal parasites ( $n=190$ specimens), values of the condition coefficients in the length classes ranged from 0.70 to 0.85 , with the mean value of 0.80 for the whole period of study (Tab. 6).

The coefficient of condition of the sea trout smolt with extremely large number of acanthocephalans in the intestine $(n=51$ individuals) amounted to 0.80 . As can be seen, the condition of the smolt did not differ from the remaining sea trout smolts examined being infected with acanthocephalans.

Presented in this paper mean values suggested that the condition of the sea trout smolts infected with intestinal parasites was similar to the condition of the fish free from parasites. Differences calculated in mean values appeared to be of little importance and amounted to 0.02 . Ranges of values of the coefficients of condition in particular length classes, in fish free from parasites and infected with them, appeared also to be similar. We can conclude that the values of coefficients of condition of smolts infected and free from parasites were similar both in mean values and in ranges in particular length classes.

\section{DISCUSSION}

Metechinorhynchus truttae (Schrank, 1788) found in the intestines of the trout smolts from the river Rega, according to Grabda is among common parasites in Poland. It has been recorded in the sea trout Salmo trutta m. trutta L. of the rivers entering the Baltic Sea like the Jelitówka, Rega, Zagórzanka, Łupawa, and Gnilna. Also Bychowski (1962) recorded its occurrence in the trout's intestine. According to Grabda (1971) and Prost (1994) it is pathogenic in high intensity of infections. It perforates walls of the intestine, causes necrosis of intestine epithelium, wealmess and often death of fish (Meyer 1932; Steinstrasser 1936 after Grabda 1971; Bychowski 1962). However, no one of the symptoms described was found in the sea trout smolts in the present survey. The intermediate host of acanthocephalans in this part of Europe - Gammarus pulex (cf. Scheer 1935 after Grabda 1971; Bychowski 1962; Prost 1994) abundantly occurs in the drainage area of the river Rega. According to Różańska (1961) Gammarus pulex is a component of diet of the lake trout (Salmo trutta m. lacustris L.) from a Pomeranian stream Trzebiocha. Piesik (1937), during investigation on intestinal parasites of of the trout (Salmo trutta L.) juveniles introduced into Pomeranian river Brda found Acanthocephalus anguillae Müller, 1780. The rate of infection of acanthocephalans in the trout juveniles calculated from the above results amounted to $17.4 \%$ and it was much lower when compared to results of our own study (72.1\%). Distribution of acanthocephalans in the intestine of trout juveniles from the Brda and the smolts presently examined appeared to be similar. According to Piesik (1937) acanthocephalans occurred from time to time in small numbers ( 3 individuals) in the pyloric caeca similarly like in trout smolts from Rega (1-5 specimens). Rate of infection of acan- 
thocephalan Neoechinorhynchus rutili (Müller, 1780) in the trout juveniles reared in ponds according to Enger (1934) (after Piesik 1937) was a yet lower and amounted to $11 \%$. Grabda et al. (1961) also recorded the occurrence of Neoechinorhynchus rutili (Müller, 1780) in the intestine of the lake trout Salmo trutta m. lacustris L. in a Pomeranian lake Wdzydze. However, the prevalence of infection amounting to $40 \%$ as well as the mean intensity ( 1.25 specimens) with the abundance 6.4 was markedly lower when referred to the infection by Metechinorhynchus truttae recorded in the present studied sea trout smolts from the drainage area of the river Rega.

Similar values of the condition coefficients of the sea trout smolts from the Rega, both for fish infected and free from intestinal parasites, did not support the suggestion of Kocyłowski and Miączyński (1960) on considerable deterioration of fish condition owing to abundant occurrence of acanthocephalans. However, some fish in the above-mentioned study survived in the river till smoltification process. Therefore further investigations on the condition of the sea trout juveniles at the parr stage grown in streams (with parasites and free from intestinal parasites) seem to be necessary. Results of such observations may give an answer on the impact of parasites ord acanthocephalans in particular on the mortality of the sea trout juveniles at the parr stage, what was discussed already by Meyer (1932) and Steinstrasser (1936) (after Grabda 1971), Linstow (1895) and Meyer (1933) (after Bychowski 1962), Kocylowski and Miączyński (1960) as well as by Prost (1994).

\section{CONCLUSIONS}

The following conclusions can be drawn from the present survey:

1. Acanthocephalan Metechinorhynchus truttae (Schrank, 1788) and cestode Cyathocephalus truncatus (Pallas, 1781) were recorded to constitute intestinal parasite fauna of the sea trout smolts from the Rega.

2. The prevalence of acanthocephalan infection reached to $72 \%$ with the abundance 6.4 , while the prevalence for the cestodes was $10.5 \%$ with the abundance 0.53 .

3. No relationship was found between the occurrence of acanthocephalans and cestodes and deterioration of condition of the sea trout smolts from the Rega.

\section{REFERENCES}

Bychowski B.E., 1962: Opredelitel' parazitov presnovodnych ryb SSSR [Key to freshwater fish parasites of the SSSR]. AN SSSR, Moskva: 522-614. (In Russian).

Chelkowski Z., 1974: Studia nad biologia troci Salmo trutta m. trutta z rzeki Regi [Studies on the biology of the sea trout Salmo trutta m. trutta from the river Rega]. Zesz. Nauk. AR w Szczecinie, Ser. Rozprawy, 37. (In Polish, English summary).

Chelkowski Z., 1978: Studies on trout (Salmo trutta L.) wild smolts of the river Rega. Acta Iehth. Piscat., 8, 2: 41-58. 
Chelkowski Z., B. Chelkowska, 1982: Biological characteristics of trout (Salmo trutta L.) smolts grown in river Mołstowa catchment area. Acta Ichth. Piscat., 12, 1: 57-68.

Grabda J., 1971: Kolcogłowy (Acanthocephala) [Acanthocephalans]. Katalog fauny Polskiej [Catalogus Faunae Poloniae], 10, PWN, Warszawa. (In Polish).

Grabda E., J. Grabda, K. Wierzbicki, 1961: Pasożyty i choroby ryb w jeziorze Wdzydze [Parasites and diseases of fishes in lake Wdzydze]. Rocz. Nauk Rol., Ser. D, 93: 239-266. (In Polish, English summary).

Kocylowski B., T. Miączyński, 1960: Choroby ryb i raków [Diseases of fish and crayfish]. PWRiL. Warszawa: 312-314. (In Polish).

Piesik J., 1937: Materiały do znajomości pasożytów przewodów pokarmowych młodocianych roczników łososi i troci, sztucznie przesiedlonych do Brdy [Contribution to the knowledge on the parasites of alimentary tracts of juvenile trout and salmon transferred to the river Brda]. Pam. PINGW, Puławy, 261 B, 17, 2: 1-14. (In Polish, German summary).

Prost M., 1994: Choroby ryb [Fish diseases]. Pol. Tow. Nauk Wet., Lublin: 200-434. (In Polish).

Różańska Z., 1961: Pokarm narybku troci jeziorowej (Salmo trutta m. lacustris L.) i innych gatunków ryb w potoku Trzebiocha [Food of fry of the lake trout Salmo trutta m. lacustris L. as well as the other species of fishes in the stream Trzebiocha]. Rocz. Nauk. Rol., Ser. D, 93: 387-421. (In Polish, English summary).

Suworow B.K., 1954: Podstawy ichtiologii [Principles of ichthyology]. PWN, Warszawa: 325-507 (In Polish).

Translated: dr B. Więcaszek

\title{
Zygmunt CHEŁKOWSKI, Bożena CHEŁKOWSKA
}

\author{
CZESTOTLIWOŚĆ WYSTĘPOWANIA KOLCOGŁOWÓW (ACANTHOCEPHALA) \\ I TASIEMCÓW (CESTODA) W PRZEWODACH POKARMOWYCH SMOLTÓW \\ TROCI WĘDROWNEJ (SALMO TRUTTA M. TRUTTA) WYROSEYCH W ZLEWNI \\ RZEKI REGI ORAZ ICH WPEYW NA KONDYCJE RYB
}

\section{STRESZCZENIE}

W badanym materiale liczącym 247 smoltów troci wędrownej kolcogłowy wystapiły w 164, tasiemce w 12, a kolcogłowy i tasiemce w 14 przewodach pokarmowych. Z powyższego wynika, że na ogólną ilość zarażonych ryb kolcogłowy wystapiły w 178, a tasiemce w 26 przewodach pokarmowych. Obecność kolcogłowów stwierdzono w piętnastu $\mathrm{z}$ występujących szesnastu jednocentymetrowych klas długości smoltów w zakresie 11-26 cm (z wyjątkiem $25 \mathrm{~cm}$ klasy długości). Tasiemce natomiast wystąpiły w sześciu i to niższych klasach długości smoltów w zakresie 12-20 cm (z wyjątkiem klasy długości 13; 18 i $19 \mathrm{~cm}$ ). Ekstensywność inwazji kolcogłowów wynosiła $72 \%$ przy średniej intensymmości zarażenia populacji 6,4 , a tasiemców odpowiednio $10,5 \%$ i 0,53 . W składzie pasożytów jelitowych występował kolcogłów Metechinorhynchus truttae (Schrank, 1788) oraz tasiemiec Cyathocephalus truncatus (Pallas, 1781). Nie stwierdzono wpływu występowania kolcogłowów i tasiemców na spadek kondycji smoltów troci wędrownej z Regi.

Received: 25 June 1996

Authors' address:

Zygmunt Chełkowski PhD DSc ProfTit

Department of Salmonid Fishes Management

Agricultural University of Szczecin

Kazimierza Królewicza 4, 71-550 Szczecin, Poland 